\title{
Intercropping with Tropaeolum majus and fertilization with chicken manure on yield of Allophylus edulis ${ }^{1}$
}

\author{
Jaqueline Silva Nascimento ${ }^{*}$ (D), Maria do Carmo Vieira², Néstor Antonio Heredia Zárate ${ }^{2}$, \\ Ademir Goelzer ${ }^{3}$, Orivaldo Benedito da Silva ${ }^{2}$, Cleberton Correira Santos ${ }^{2}$
}

10.1590/0034-737X201966050004

\begin{abstract}
Proper crop management is essential for preservation of medicinal plants of the Cerrado. There is no report of ex-situ cultivation of Allophylus edulis (vacum), which is used for its antimicrobial and antioxidant activities, in intercropping with Tropaeolum majus (nasturtium). Therefore, the aim of this study was to evaluate the effects of the intercropping with nasturtium and fertilization with chicken manure on yield of vacum. The experiment consisted of six treatments: monocrop vacum without chicken manure; monocrop vacum with hicken manure; monocrop nasturtium without chicken manure; monocrop nasturtium with chicken manure; vacum intercropped with nasturtium without chicken manure and vacum intercropped with nasturtium with chicken manure. The crop cycle of vacum took 540 days after transplanting and, during this period, nasturtium was cultivated in two cycles, in 2017 and 2018. Vacum showed greater height growth and production of fresh and dry masses of leaves in single cultivation with chicken manure fertilization. Nasturtium showed greater growth and flower production in monocrop cultivation with chicken manure fertiliazation, in the first cycle. The intercropping vacum with nasturtium was effective, showing Equivalent Area Ratio (EAR) of 1.16 and 1.18 without and with chicken manure, respectively.
\end{abstract}

Keywords: nasturtium; vacum; organic waste; plant arrangement.

\section{INTRODUCTION}

Proper crop management is essential for preservation of native medicinal plants. Cerrado is one of the biomes that are rich in species of economic interest. It is the second largest Brazilian vegetation unit and is considered the richest in plant species among the world's Savannas. Hence, the risk of biodiversity loss due to intensification of farming activities, spread of exotic species, deforestation, burnings, and degradation of natural resources (Fernandes et al., 2016).

The exploitation of medicinal plant genetic resources is associated with extractive activities, making them more susceptible to extinction (Fernandes et al., 2016; Jeromini et al., 2018). Therefore, the need for studies regarding cultivation practices, including intercropping, with advantages such as proper use of natural resources, harvest at different times, maximization of space with species of different habits, use of organic waste, greater growth and yield of the species (Brito et al., 2017).

Allophylus edulis (A. St.-Hil., A. Juss. Cambess.) Hieron. ex Niederl (vacum, Sapindaceae) is native to Brazil, occurring in the Cerrado of Mato Grosso do Sul and Minas Gerais. Its leaves have medicinal properties against throat inflammations (Trevizan et al., 2016), diarrhea (Umeo et al., 2011), and antimicrobial and antioxidant activities due to the presence of phenolic compounds such as alkaloids, flavonoids, and essential oils (steroid and

\footnotetext{
Submitted on May 06 $6^{\text {th }}, 2019$ and accepted on August $27^{\text {th }}, 2019$

${ }^{1}$ This paper is part of the first author's Doctoral thesis. Financial source: National Council for Scientific and Technological Development - CNPq.

${ }^{2}$ Universidade Federal da Grande Dourados, Departamento de Ciências Agrárias, Dourados, Mato Grosso do Sul, Brazil. Jaque24nascimento@hotmail.com; mariavieira@ufgd.edu.br; nestorzarate@ufgd.edu.br; orivaldo.bio@gmail.com; cleber_frs@yahoo.com.br

${ }^{3}$ Universidade Federal de Lavras, Departamento de Biotecnologia Vegetal, Lavras, Minas Gerais, Brazil. ademirgoelzer2008@hotmail.com

*Corresponding author: jaque24nascimento@ hotmail.com
} 
triterpenoid) in its chemical composition (Tirloni et al., 2015). Economically, it is used as wood in carpentry and afforestation of cities; the ripe fruits are sweet and eaten by birds and other animals (Umeo et al., 2011; Trevizan et al., 2016).

Tropaeolum majus L. (nasturtium, Tropaeolaceae) has potential to be intercropped with vacum. Nasturtium is an edible plant with medicinal properties against cardiovascular disorders (Jakubczyk et al., 2018), urinary tract infections, antiseptic and expectorant activities (Melo et al., 2018). As a vegetable, the whole aerial part is used for human consumption, with leaves and flowers being sources of vitamin C and mineral salts (Jakubczyk et al., 2018).

Literature reviews have shown that there were no studies regarding the intercropping of vacum with nasturtium or addressing its growth and yield, indicating the importance of preserving this species native to the Cerrado, decreasing the risk of extinction, fighting indiscriminate use, and using proper cultivation management (Fernandes et al., 2016; Oliveira et al., 2015). Intercropping of medicinal plants has been studied by some authors (Brito et al., 2017; Moraes et al., 2007); however, investigations with species native to Cerrado are still lacking, making researches that generate knowledge to provide rational use of natural resources necessary.

In addition to intercropping, the use of organic waste as chicken manure, which is a primary source of nutrients, can contribute to reduce reliance on agricultural inputs, as well as to provide a sustainable destination for these materials (Torales et al., 2014; Rogeri et al., 2015). Organic manure can increase medicinal plant production by promoting slow and gradual release of nutrients to the soil over time and improving physical, chemical, and biological attributes of the soil such as reduction of soil density, increase in soil porosity, and increase in soil-water retention (Costa et al., 2009), increase in cation exchange capacity, increase levels of $\mathrm{P}, \mathrm{K}, \mathrm{Ca}, \mathrm{Mg}, \mathrm{Cu}$ and $\mathrm{Zn}$ (Rogeri et al., 2015), and increase soil microbial respiration (Andrade $e t$ al., 2015).

The beneficial effect of organic wastes to plants has been demonstrated by Bonamigo et al. (2016), who found that the substrate composed of soil, sand and poultry manure favored the growth and quality of seedlings of Tocoyena formosa (Cham. \& Schltdl.) K. Schum. Bortolini et al. (2017) reported that poultry manure with sewage sludge improved height and diameter growth rates of seedlings of Cedrela fissilis and Anadenanthera macrocarpa (Benth). Brenan. Sangalli et al. (2004) found that chicken manure added of nitrogen enhanced plant growth and flower production in Tropaeolum majus L. However, limited studies are available on intercropping with native medicinal plants and animal manure fertilization. Thus, the aim of this study was to assess the yield of vacum intercropped with nasturtium and fertilization with chicken manure.

\section{MATERIAL AND METHODS}

The experiment was performed in the Medicinal Plant Garden ( $22^{\circ} 1316^{\prime \prime S}$ and $54^{\circ} 1701^{\prime \prime} \mathrm{W}, 452 \mathrm{~m}$ altitude) of the Universidade Federal da Grande Dourados, Dourados-MS, from July 2017 to October 2018. The soil is classified as Dystroferric Red Latosol (Embrapa, 2013) and the climate as mesothermal humid, type Am, tropical, with rainy summers. Temperature range from 20 to $24^{\circ} \mathrm{C}$ and annual rainfall from 1250 to $1500 \mathrm{~mm}$ (Alvares et al., 2013). Temperatures and rainfall during cultivation are shown in Figure 1.

Vacum and nasturtium cv. 'Jewel' were studied in monocrop and intercrop systems, with or without addition of of $15 \mathrm{t} \mathrm{ha}^{-1}$ chicken manure to the soil. The experiment consisted of six treatments as follows: monocrop vacum without chicken manure; monocrop vacum with chicken manure; monocrop nasturtium without chicken manure; monocrop nasturtium with chicken manure; vacum intercropped with nasturtium without chicken manure and vacum intercropped with nasturtium with chicken manure. The experiment was arranged in a randomized block design with four replicates. Each plot had an area of $2.5 \mathrm{~m}^{2}(1 \mathrm{~m}$ wide and $2.5 \mathrm{~m}$ long), with one row of vacum with five plants spaced $0.50 \mathrm{~m}$, with population of 20.000 plants ha- $^{-1}$, and two rows of nasturtium with ten plants each spaced $0.50 \mathrm{~m}$ between rows and $0.25 \mathrm{~cm}$ between plants, with population of 75.000 plants ha ${ }^{-1}$. The same spacings were used in the plots with intercrop, and the total field experiment size was $75 \mathrm{~m}^{2}$.

The species were propagated in polystyrene trays with 128 cells, using Bioplant ${ }^{\circledR}$ substrate, in protected environment with $50 \%$ shading. Vacum seeds were extracted from fruits randomly harvested (Registration SISGEN number A9CDAAE) from plants of natural populations in Dourados-MS (22 $08^{\prime} 23.24$ "S and 550' 16.84"W, 487 m altitude).

Seeds of a commercial variety of nasturtium were purchased from Isla ${ }^{\circledR}$ Sementes. When the vacum seedlings reached $15 \mathrm{~cm}$ in height, they were transferred to tubes and transplanted to the field with about $50 \mathrm{~cm}$ in height, at one year of age. Nasturtium was cultivated in two cycles, in 2017 and 2018. In the first cycle, 2017, the seedlings were transplanted 25 days after sowing (DAS) on the same day that vacum was transplanted, and in the second cycle, 2018, at 190 days after vacum transplanting, both with about $12 \mathrm{~cm}$ in height.

The planting area was prepared by plowing and harrowing and seedbeds were prepared with a rotary cultivator. Chicken manure was added to the respective plots, 
at $0.0-0.20 \mathrm{~m}$ depth, using a rotary cultivator, on the day after the transplanting. Chicken manure contained $260.0 \mathrm{~g}$ $\mathrm{kg}^{-1} \mathrm{C}_{\text {organic }} ; 15.36 \mathrm{~g} \mathrm{~kg}^{-1} \mathrm{P}_{\text {total }} ; 20.0 \mathrm{~g} \mathrm{~kg}^{-1} \mathrm{~K}_{\text {total }} ; 23.9 \mathrm{~g} \mathrm{~kg}^{-1}$ $\mathrm{N}_{\text {total; }}$ and $447.0 \mathrm{~g} \mathrm{~kg}^{-1} \mathrm{MO}$, and $\mathrm{C} / \mathrm{N}=10.87$. Sprinkler irrigation was performed to maintain soil moisture at $70 \%$ field capacity. Weeding was carried out by hand when necessary.

The characteristics assessed for the vacum plants were as follows: collar diameter and height measured every 30 days, from 30 to 540 days after transplanting - DAT. Fruits were harvested weekly, in 2017 (90 to 120 DAT) and 2018 (420 to 510 DAT), and after weighing, the production was summed up to determine the total production of each year. At 540 DAT, plants were harvested by cutting at $0.50 \mathrm{~m}$ above the collar, fresh and dry masses of leaves and stems weighed, and leaf area assessed using a leaf area integrator LI 3100 (LI-COR, Lincoln, Nebraska, USA).

After weighing, the leaves were dried to constant mass in a forced air circulation oven at $65^{\circ} \mathrm{C} \pm 5{ }^{\circ} \mathrm{C}$ to determine the dry mass. Then, the material was ground in a Willey type mill for further analysis of macro and micronutrient content, according to Malavolta (2006). Soil samples from all treatments were collected to perform the characterization of the chemical attributes. The nasturtium plants had their height measured during the cultivation cycles and flowers in anthesis were harvested for assessment of number and fresh and dry masses.

The following physiological parameters of vacum and nasturtium plants were assessed: transpiration $(E)$ and photosynthetic $(A)$ rate, stomatal conductance $(g s)$, intercellular $\mathrm{CO}_{2}$ concentration $(\mathrm{Ci})$, instantaneous water use efficiency $\left(A E^{-1}-W U E\right)$, instantaneous carboxylation $\left(A C i^{-1}-I C E\right)$, and intrinsic water use efficiency $\left(\mathrm{A} \mathrm{Gs}^{-1}\right.$ $W U E i$, ìmol $\mathrm{mol}^{-1}$ ). The parameters were assessed in fully expanded leaves of vacum plants at 30, 60, 90, 120, 420,
450, 480, and 510 DAT and in nasturtium leaves at 30, 60, 90, and 120 DAT in each cycle, in the morning, using an infrared gas analyzer - IRGA (LICor, model LI-6400, ADC System) with $300 \mathrm{~mL} \mathrm{~min}^{-1}$ airflow and a $995 \mu \mathrm{mol} \mathrm{m} \mathrm{m}^{-2} \mathrm{~s}^{-1}$ light source. The chlorophyll index (CI) was determined using a portable chlorophyllometer (ClorofiLOG CFL 1030 Falker).

The efficiency of the intercropping was assessed using the Equivalent Area Ratio (EAR) (Caetano et al., 1999), with the equation: $\mathrm{EAR}=(\mathrm{Cv} / \mathrm{Sv})+(\mathrm{Cn} / \mathrm{Sn})$; where $\mathrm{Cv}$ and $\mathrm{Cn}=$ vacum and nasturtium productions in the intercropping and $\mathrm{Sv}$ and $\mathrm{Sn}=$ vacum and nasturtium productions in monocropping.

Data were subjected to analysis of variance by the $\mathrm{F}$ test, and means were compared by the Tukey's test ( $\mathrm{p} \leq$ 0.05). Data assessed during the cultivation cycles were analyzed as plots subdivided in time, subjected to analysis of variance by the $\mathrm{F}$ test, and regression models were adjusted at $5 \%$. Principal component analysis was used to understand the relationship among intercropp, monocrop, and chicken manure (Sneath \& Sokal, 1973).

\section{RESULTS}

The soil in the intercropping system with addition of chicken manure had the highest contents of P, K, SB, V\% and lowest $\mathrm{Al}$, at the end of the crop cycle. Monocrop vacum with addition of chicken manure had higher contents of $\mathrm{K}, \mathrm{OM}$ and $\mathrm{SB}$; and monocrop nasturtium with chicken manure had higher contents of $\mathrm{OM}$ and $\mathrm{Zn}$. The contents of $\mathrm{Ca}, \mathrm{Mg}, \mathrm{Cu}, \mathrm{Mn}, \mathrm{Fe}, \mathrm{pH}, \mathrm{H}+\mathrm{Al}$, and $\mathrm{CEC}$ were not different among the factors under study (Table 1).

Chemical attributes of vacum leaves cultivated with addition of chicken manure had higher content of $\mathrm{N}$, regardless of being intercropped, while $\mathrm{P}$ was higher in

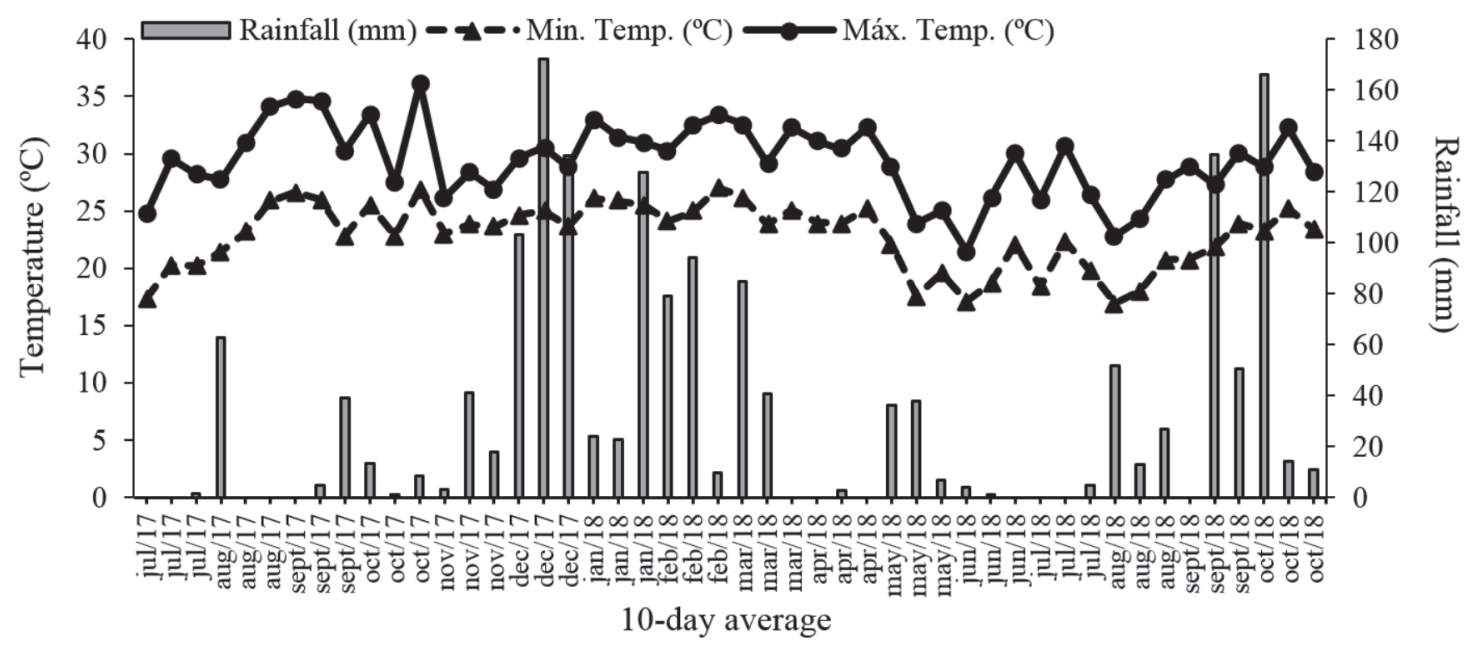

Figure 1: Maximum and minimum 10-day temperature and rainfall averages, from July 10, 2017 to October 27, 2018. (Source: clima.cpao.embrapa.br). 
With chicken manure

\section{Attributes}

$\mathrm{P}\left(\mathrm{mg} \mathrm{dm} \mathrm{m}^{-3}\right)$

$\mathrm{K}\left(\mathrm{mmolc} \mathrm{dm}^{-3}\right)$

$\mathrm{Ca}\left(\mathrm{mmolc} \mathrm{dm}^{-3}\right)$

$\operatorname{Mg}\left(\mathrm{mmolc} \mathrm{dm}^{-3}\right)$

$\mathrm{Cu}\left(\mathrm{mg} \mathrm{dm}^{-3}\right)$

$\operatorname{Mn}\left(\mathrm{mg} \mathrm{dm}^{-3}\right)$

$\mathrm{Fe}\left(\mathrm{mg} \mathrm{dm}^{-3}\right)$

$\mathrm{Zn}\left(\mathrm{mg} \mathrm{dm}^{-3}\right)$

$\mathrm{OM}\left(\mathrm{g} \mathrm{dm}^{-3}\right)$

$\mathrm{pH}$

$\mathrm{Al}\left(\mathrm{mmolc} \mathrm{dm}^{-3}\right)$

$\mathrm{H}+\mathrm{Al}\left(\right.$ mmolc dm $\left.\mathrm{dm}^{-3}\right)$

$\mathrm{SB}\left(\mathrm{mmolc} \mathrm{dm}^{-3}\right)$

CEC $\left(\right.$ mmolc $\left.\mathrm{dm}^{-3}\right)$

$\mathrm{V} \%$

5.09
Means followed by the same letters in the

by the same letters in the rows are not significantly different by the 1

magnesium $(\mathrm{Mg})$, copper $(\mathrm{Cu})$, manganese $(\mathrm{Mn})$, iron $(\mathrm{Fe})$, zinc $(\mathrm{Zn})$, or

capacity (CEC), and base saturation (V\%). C.V. - coefficient of variation.

Without chicken manure

\begin{tabular}{|c|c|c|c|c|c|c|}
\hline & & \multirow{2}{*}{ C.V. $(\%$} \\
\hline Vacum & Nasturtium & Consortium & Vacum & Nasturtium & Consortium & \\
\hline $51.17 \pm 13.65 \mathrm{ab}$ & $51.82 \pm 23.78 \mathrm{ab}$ & $54.97 \pm 20.06 a$ & $17.67 \pm 5.52 b$ & $24.00 \pm 7.38 \mathrm{ab}$ & $31.15 \pm 5.22 \mathrm{ab}$ & 40.39 \\
\hline $2.10 \pm 0.09 \mathrm{a}$ & $1.70 \pm 0.07 \mathrm{ab}$ & $2.00 \pm 0.05 \mathrm{a}$ & $0.90 \pm 0.01 \mathrm{ab}$ & $0.70 \pm 0.01 \mathrm{~b}$ & $1.20 \pm 0.01 \mathrm{ab}$ & 35.88 \\
\hline $75.00 \pm 0.54 \mathrm{a}$ & $75.00 \pm 0.85 \mathrm{a}$ & $72.50 \pm 0.79 \mathrm{a}$ & $65.00 \pm 0.33 a$ & $62.50 \pm 0.40 \mathrm{a}$ & $62.50 \pm 0.31 \mathrm{a}$ & 9.29 \\
\hline $22.50 \pm 0.16 \mathrm{a}$ & $25.00 \pm 0.21 \mathrm{a}$ & $22.50 \pm 0.10 \mathrm{a}$ & $20.00 \pm 0.30 \mathrm{a}$ & $20.00 \pm 0.15 \mathrm{a}$ & $20.00 \pm 0.05 \mathrm{a}$ & 14.60 \\
\hline $13.25 \pm 0.37 \mathrm{a}$ & $13.00 \pm 0.85 \mathrm{a}$ & $13.75 \pm 0.23 a$ & $12.50 \pm 1.09 \mathrm{a}$ & $12.75 \pm 0.81 \mathrm{a}$ & $13.25 \pm 0.71 \mathrm{a}$ & 6.59 \\
\hline $92.00 \pm 2.93 \mathrm{a}$ & $86.75 \pm 9.43 \mathrm{a}$ & $78.75 \pm 6.87 \mathrm{a}$ & $82.00 \pm 7.59 \mathrm{a}$ & $76.75 \pm 9.71 \mathrm{a}$ & $86.50 \pm 8.15 \mathrm{a}$ & 8.26 \\
\hline $123.75 \pm 15.55 \mathrm{a}$ & $123.00 \pm 11.48 \mathrm{a}$ & $132.25 \pm 27.22 \mathrm{a}$ & $139.25 \pm 24.01 \mathrm{a}$ & $135.00 \pm 15.91 \mathrm{a}$ & $145.75 \pm 22.39 a$ & 15.38 \\
\hline $4.75 \pm 0.84 \mathrm{ab}$ & $5.00 \pm 1.24 \mathrm{a}$ & $3.50 \pm 1.08 \mathrm{ab}$ & $3.50 \pm 0.53 \mathrm{ab}$ & $3.50 \pm 0.46 \mathrm{ab}$ & $2.75 \pm 0.51 b$ & 23.49 \\
\hline $33.75 \pm 0.62 \mathrm{a}$ & $31.75 \pm 2.97 \mathrm{a}$ & $30.50 \pm 1.54 \mathrm{ab}$ & $29.25 \pm 2.53 \mathrm{ab}$ & $26.25 \pm 2.80 \mathrm{~b}$ & $26.50 \pm 3.07 \mathrm{~b}$ & 7.62 \\
\hline $5.25 \pm 0.12 \mathrm{a}$ & $5.35 \pm 0.07 \mathrm{a}$ & $5.32 \pm 0.08 \mathrm{a}$ & $5.11 \pm 0.12 \mathrm{a}$ & $5.18 \pm 0.07 \mathrm{a}$ & $5.35 \pm 0.09 \mathrm{a}$ & 2.01 \\
\hline $0.90 \pm 0.06 \mathrm{ab}$ & $0.60 \pm 0.06 \mathrm{ab}$ & $0.30 \pm 0.06 \mathrm{~b}$ & $2.10 \pm 0.06 \mathrm{a}$ & $1.50 \pm 0.06 \mathrm{ab}$ & $1.20 \pm 0.09 \mathrm{ab}$ & 59.75 \\
\hline $34.70 \pm 0.23 \mathrm{a}$ & $32.90 \pm 0.10 \mathrm{a}$ & $33.50 \pm 0.06 \mathrm{a}$ & $38.80 \pm 0.73 a$ & $33.40 \pm 0.26 \mathrm{a}$ & $33.30 \pm 0.15 \mathrm{a}$ & 8.74 \\
\hline $2.10 \pm 0.09 \mathrm{a}$ & $1.60 \pm 0.07 \mathrm{ab}$ & $2.00 \pm 0.05 \mathrm{a}$ & $0.90 \pm 0.01 \mathrm{ab}$ & $0.80 \pm 0.01 \mathrm{~b}$ & $1.20 \pm 0.01 \mathrm{ab}$ & 36.69 \\
\hline $36.60 \pm 0.30 \mathrm{a}$ & $34.10 \pm 0.14 \mathrm{a}$ & $34.90 \pm 0.07 \mathrm{a}$ & $39.90 \pm 0.77 \mathrm{a}$ & $34.70 \pm 0.34 \mathrm{a}$ & $35.10 \pm 0.18 \mathrm{a}$ & 8.23 \\
\hline $5.40 \pm 2,47 \mathrm{ab}$ & $4.67 \pm 1.86 \mathrm{ab}$ & $5.82 \pm 1.27 \mathrm{a}$ & $2.60 \pm 0.33 b$ & $2.35 \pm 0.33 b$ & $3.40 \mathrm{ab} \pm 0.21 \mathrm{~b}$ & 33.00 \\
\hline
\end{tabular}

0.39

35.88

6.59

3.49

7.62

9.75

8.74

8.23 33.00 
leaves of plants in intercropping without chicken manure. The contents of $\mathrm{Ca}$ and $\mathrm{Mn}$ were higher in monocropping with addition of chicken manure, differing only from the intercropping without addition of chicken manure. Foliar contents of $\mathrm{K}, \mathrm{Mg}, \mathrm{Cu}$, and $\mathrm{Zn}$ were not different among the factors under study in monocropping (Table 2). Intercropped nasturtium with addition of chicken manure had higher foliar content of $\mathrm{N}$ and $\mathrm{K}$ (Table 2).

Over the cycle, the growth in height of vacum plants was linear, being greater in monocropping, with the maximum height of $147.17 \mathrm{~cm}$ at 540 DAT (Figure 2A). The greatest stem diameter of vacum plants was achieved in monocropping, with maximum of $21.06 \mathrm{~mm}$ at 540 DAT (Figure 2B), while with the addition of chicken manure, the maximum diameter was $20.66 \mathrm{~mm}$ at 540 DAT (Figure 2C).

The maximum heights of nasturtium plants occurred in the treatment with addition of chicken manure, $28.76 \mathrm{~cm}$ at 98 DAT in 2017 (Figure 3A), and $23.34 \mathrm{~cm}$ at 128 DAT, in 2018, in monocrop (Figure 3B).

The physiological parameters of vacum plants showed higher photosynthetic rate $(A)$, intercellular $\mathrm{CO}_{2}$ concentration $(\mathrm{Ci})$, instantaneous water use efficiency (WUE), intrinsic water use efficiency (WUEi), and indexes of Chlorophyll $a$ and total with addition of chicken manure, regardless of the intercropping. On the other hand, the transpiration rate $(E)$ was greater in the intercropping without addition of chicken manure. The stomatal conductance $(g s)$, instantaneous carboxylation efficiency (ICE), and Chlorophyll $b$ index showed no difference among the factors under study (Table 3 ). The indexes of Chlorophyll $a, b$, and total in nasturtium plants were higher with addition of chicken manure, regardless of the intercropping and cycles (Table 3 ).

Regarding the physiological parameters of nasturtium plants, the lowest intercellular $\mathrm{CO}_{2}$ concentration $(\mathrm{Ci})$ (280 $\mu \mathrm{mol} \mathrm{mol}{ }^{-1} ; \mathrm{w}=384.656250-2.678021 * \mathrm{x}+0.017135^{*} \mathrm{x}^{2}$; $\left.\mathrm{R}^{2}=0.88\right)$ was recorded in the 2017 cycle at 78 DAT. The stomatal conductance $(\mathrm{gs})$ (from 0.375 to $0.185 \mu \mathrm{mol} \mathrm{mol}^{-1}$; $\left.\mathrm{w}=0.3957-0.0018 * \mathrm{x} ; \mathrm{R}^{2}=0.75\right)$ decreased over the cultivation cycle, regardless of the intercropping and addition of chicken manure.

In the second crop cycle of nasturtium, the maximum stomatal conductance $(g s)$ of $0.30 \mu \mathrm{mol} \mathrm{mol}{ }^{-1}(\mathrm{w}=-$ $0.0059+0.0082 * \mathrm{x}-0.000066 * \mathrm{x}^{2} ; \mathrm{R}^{2}=0.77$ ) was recorded at 62 DAT and the maximum instantaneous carboxilation efficiency (ICE) of $0.03 \mathrm{~mol} \mathrm{~m}^{-2} \mathrm{~s}^{-1}(\mathrm{w}=-0.0004+0.0012 * \mathrm{x}-$ $\left.0.000009^{*} \mathrm{x}^{2} ; \mathrm{R}^{2}=0.95\right)$ at 66 DAT. The maximum transpiraton rate $(E)$ of $5.07 \mathrm{mmol} \mathrm{m}^{-2} \mathrm{~s}^{-1}(\mathrm{w}=2.802187+0.084430 * \mathrm{x}-$ $\left.0.000784 * \mathrm{x}^{2} ; \mathrm{R}^{2}=0.90\right)$ was recorded at $53 \mathrm{DAT}$ and the maximum photosynthetic rate $(A)$ of $11.48 \mu \mathrm{mol} \mathrm{m}{ }^{-2} \mathrm{~s}^{-1}$ $\left(\mathrm{w}=1.4632+0.3102 * \mathrm{x}-0.0024 * \mathrm{x}^{2} ; \mathrm{R}^{2}=0.99\right)$, at 64 DAT, regardless of the intercropping and addition of chicken manure.

Table 2: Contents of macro and micronutrients in leaves of vacum and nasturtium in monocropping and intercropping systems, with and without addition of chicken manure

\begin{tabular}{|c|c|c|c|c|c|}
\hline \multirow{3}{*}{ Nutrient } & \multicolumn{2}{|c|}{ With chicken manure } & \multicolumn{2}{|c|}{ Without chicken manure } & \multirow{3}{*}{ C. V. $(\%)$} \\
\hline & \multicolumn{4}{|c|}{ Vacum } & \\
\hline & Monocrop & Intercrop & Monocrop & Intercrop & \\
\hline $\mathrm{N}\left(\mathrm{g} \mathrm{kg}^{-1}\right)$ & $138.60 \pm 1.14 \mathrm{a}$ & $136.50 \pm 8.66 \mathrm{a}$ & $51.10 \pm 14.56 \mathrm{~b}$ & $43.75 \pm 10.19 \mathrm{~b}$ & 40.80 \\
\hline $\mathrm{P}\left(\mathrm{g} \mathrm{kg}^{-1}\right)$ & $3.74 \pm 0.70 \mathrm{ab}$ & $4.07 \pm 0.64 \mathrm{ab}$ & $2.95 \pm 0.23 \mathrm{~b}$ & $4.25 \pm 0.48 \mathrm{a}$ & 15.31 \\
\hline $\mathrm{K}\left(\mathrm{g} \mathrm{kg}^{-1}\right)$ & $1.83 \pm 0.42 \mathrm{a}$ & $1.92 \pm 0.58 \mathrm{a}$ & $1.54 \pm 0.30 \mathrm{a}$ & $1.82 \pm 0.42 \mathrm{a}$ & 27.15 \\
\hline $\mathrm{Ca}\left(\mathrm{g} \mathrm{kg}^{-1}\right)$ & $11.57 \pm 1.28 \mathrm{a}$ & $11.18 \pm 1.21 \mathrm{ab}$ & $9.93 \pm 0.76 \mathrm{ab}$ & $9.25 \pm 0.76 \mathrm{~b}$ & 9.84 \\
\hline $\operatorname{Mg}\left(\mathrm{g} \mathrm{kg}^{-1}\right)$ & $3.68 \pm 0.31 \mathrm{a}$ & $3.59 \pm 0.40 \mathrm{a}$ & $3.53 \pm 0.31 \mathrm{a}$ & $3.59 \pm 0.26 \mathrm{a}$ & 5.10 \\
\hline $\mathrm{Cu}\left(\mathrm{mg} \mathrm{kg}^{-1}\right)$ & $4.11 \pm 0.28 \mathrm{a}$ & $4.03 \pm 0.52 \mathrm{a}$ & $3.54 \pm 0.35 \mathrm{a}$ & $3.76 \pm 0.44 \mathrm{a}$ & 9.38 \\
\hline $\operatorname{Mn}\left(\mathrm{mg} \mathrm{kg}^{-1}\right)$ & $96.89 \pm 8.51 \mathrm{a}$ & $86.76 \pm 7.05 a b$ & $84.89 \pm 11.67 \mathrm{ab}$ & $69.87 \pm 3.31 \mathrm{~b}$ & 9.39 \\
\hline $\mathrm{Zn}\left(\mathrm{mg} \mathrm{kg}^{-1}\right)$ & $20.67 \pm 7.24 \mathrm{a}$ & $22.45 \pm 12.62 \mathrm{a}$ & $14.00 \pm 6.27 \mathrm{a}$ & $23.85 \pm 5.45 \mathrm{a}$ & 42.62 \\
\hline \multicolumn{6}{|c|}{ Nasturtium } \\
\hline $\mathrm{N}\left(\mathrm{g} \mathrm{kg}^{-1}\right)$ & $123.55 \pm 8.03 \mathrm{a}$ & $104.30 \pm 17.63 \mathrm{a}$ & $7.00 \pm 1.97 \mathrm{~b}$ & $12.25 \pm 2.39 \mathrm{~b}$ & 49.43 \\
\hline $\mathrm{P}\left(\mathrm{g} \mathrm{kg}^{-1}\right)$ & $6.72 \pm 0.79 \mathrm{a}$ & $7.27 \pm 1.25 \mathrm{a}$ & $6.06 \pm 1.45 \mathrm{a}$ & $5.33 \pm 0.91 \mathrm{a}$ & 15.15 \\
\hline $\mathrm{K}\left(\mathrm{g} \mathrm{kg}^{-1}\right)$ & $3.79 \pm 1.04 \mathrm{~b}$ & $5.66 \pm 0.63 \mathrm{a}$ & $6.05 \pm 0.66 \mathrm{a}$ & $3.57 \pm 0.51 \mathrm{~b}$ & 12.81 \\
\hline $\mathrm{Ca}\left(\mathrm{g} \mathrm{kg}^{-1}\right)$ & $19.02 \pm 2.79 \mathrm{a}$ & $22.00 \pm 5.42 \mathrm{a}$ & $17.15 \pm 11.77 \mathrm{a}$ & $17.44 \pm 10.08 \mathrm{a}$ & 37.92 \\
\hline $\operatorname{Mg}\left(\mathrm{g} \mathrm{kg}^{-1}\right)$ & $4.47 \pm 0.30 \mathrm{a}$ & $4.52 \pm 0.30 \mathrm{a}$ & $3.53 \pm 2.35 \mathrm{a}$ & $4.64 \pm 0.32 \mathrm{a}$ & 27.20 \\
\hline $\mathrm{Cu}\left(\mathrm{mg} \mathrm{kg}^{-1}\right)$ & $21.41 \pm 17.28 \mathrm{a}$ & $12.25 \pm 4.43 \mathrm{a}$ & $16.85 \pm 4.62 \mathrm{a}$ & $17.95 \pm 6.46 \mathrm{a}$ & 52.35 \\
\hline $\operatorname{Mn}\left(\mathrm{mg} \mathrm{kg}^{-1}\right)$ & $138.51 \pm 26.48 \mathrm{a}$ & $113.21 \pm 21.06 \mathrm{a}$ & $127.11 \pm 25.52 \mathrm{a}$ & $128.01 \pm 26.17 \mathrm{a}$ & 23.04 \\
\hline $\mathrm{Zn}\left(\mathrm{mg} \mathrm{kg}^{-1}\right)$ & $58.20 \pm 20.92 \mathrm{a}$ & $72.00 \pm 13.92 \mathrm{a}$ & $76.09 \pm 20.19 \mathrm{a}$ & $75.80 \pm 16.53 \mathrm{a}$ & 17.60 \\
\hline
\end{tabular}

Means followed by the same letters in the rows are not significantly different by the Tukey's test at the level of $5 \%$ of probability $(\mathrm{p}>0.05)$. Nitrogen $(\mathrm{N})$, phosphorus $(\mathrm{P})$, potassium $(\mathrm{K})$, calcium $(\mathrm{Ca})$, magnesium $(\mathrm{Mg})$, copper $(\mathrm{Cu})$, manganese $(\mathrm{Mn})$, and zinc $(\mathrm{Zn})$. C.V. - coefficient of variation. 
The maximum intercellular $\mathrm{CO}_{2}$ concentration $(\mathrm{Ci})$ (290.84 $\mu \mathrm{mol} \mathrm{mol}{ }^{-1} ; \mathrm{w}=254.2254+0.5715^{*} \mathrm{x}-0.0032 * \mathrm{x}^{2}$; $\left.\mathrm{R}^{2}=0.76\right)$ and reduction in instantaneous carboxylation efficiency (ICE) $\left(0.026 \mathrm{~mol} \mathrm{~m} \mathrm{~m}^{-2} \mathrm{~s}^{-1} ; \mathrm{w}=0.0331\right.$ $\left.0.0002 x+0.000001 * x^{2} ; R^{2}=0.79\right)$ were found at $210 \mathrm{DAT}$, regardless of the intercropping and addition of chicken manure, since at low concentrations of $\mathrm{CO}_{2}$, photosynthetic rates are limited (Taiz et al., 2017).

Fresh and dry masses of leaves and leaf area of vacum were higher in monocropping with addition of chicken manure, except for fresh mass of leaves that did not differ with or without addition of chicken manure. The fresh and dry mass of stems showed no difference between treatments (Table 4). No difference was found for fruit production of vacum as a function of the treatments, with mean fresh mass of $4.29 \mathrm{~g} \mathrm{plant}^{-1}$ and dry mass of $1.25 \mathrm{~g}$ plant $^{-1}$, probably due to the short period of assessment, since the species is perennial.

The flower production of nasturtium was maximum with addition of chicken manure in the first cycle, regardless of the intercropping, producing the greatest number $(113.54$ plant $\left.^{-1}\right)$, fresh mass $\left(69.21 \mathrm{~g} \mathrm{plant}^{-1}\right)$, and dry mass $(5.17 \mathrm{~g}$
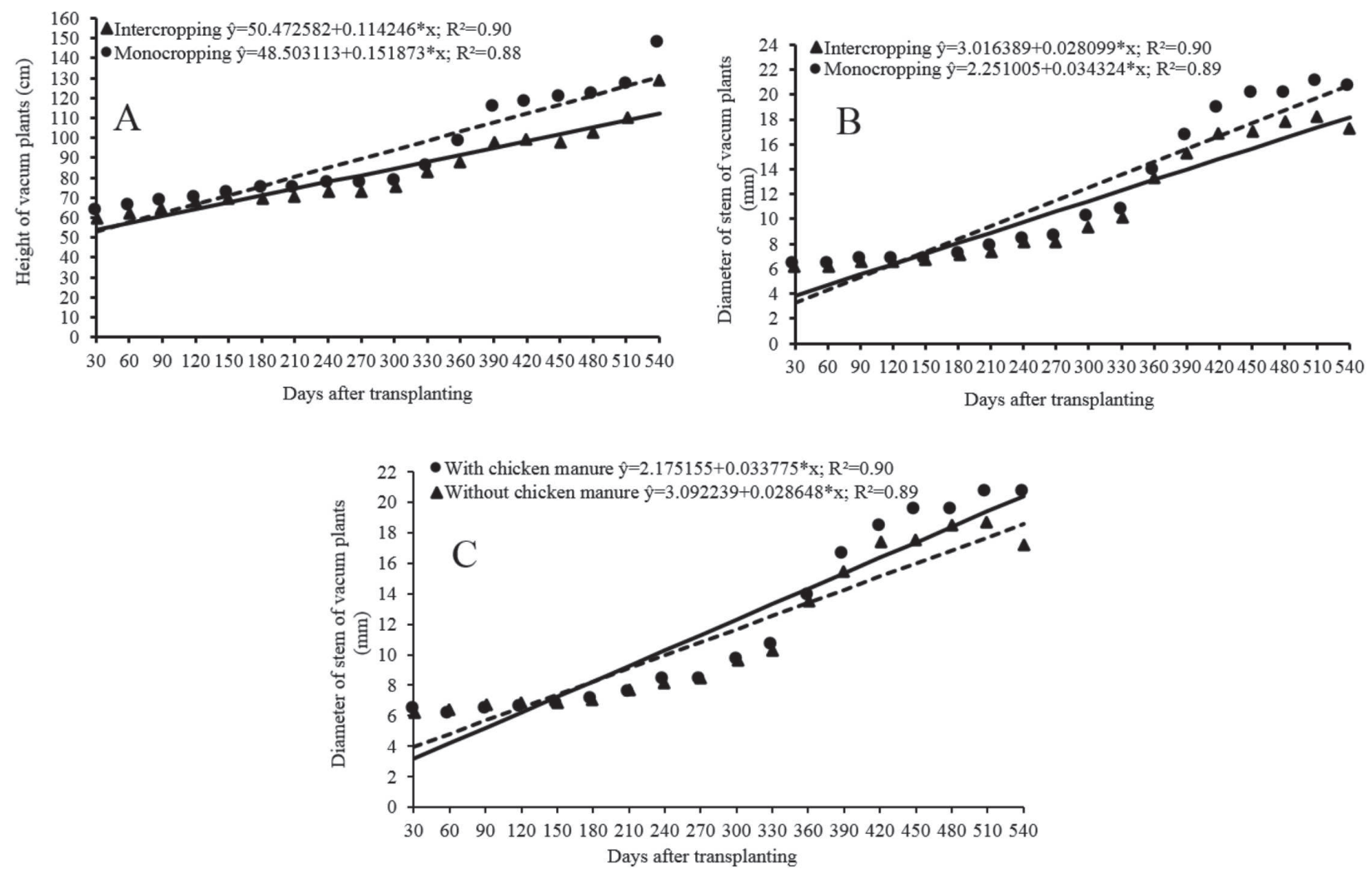

Figure 2: Plant height (A) and stem diameter of vacum as a function of days after transplanting, in intercropping (B) and addition of chicken manure to the soil (C).
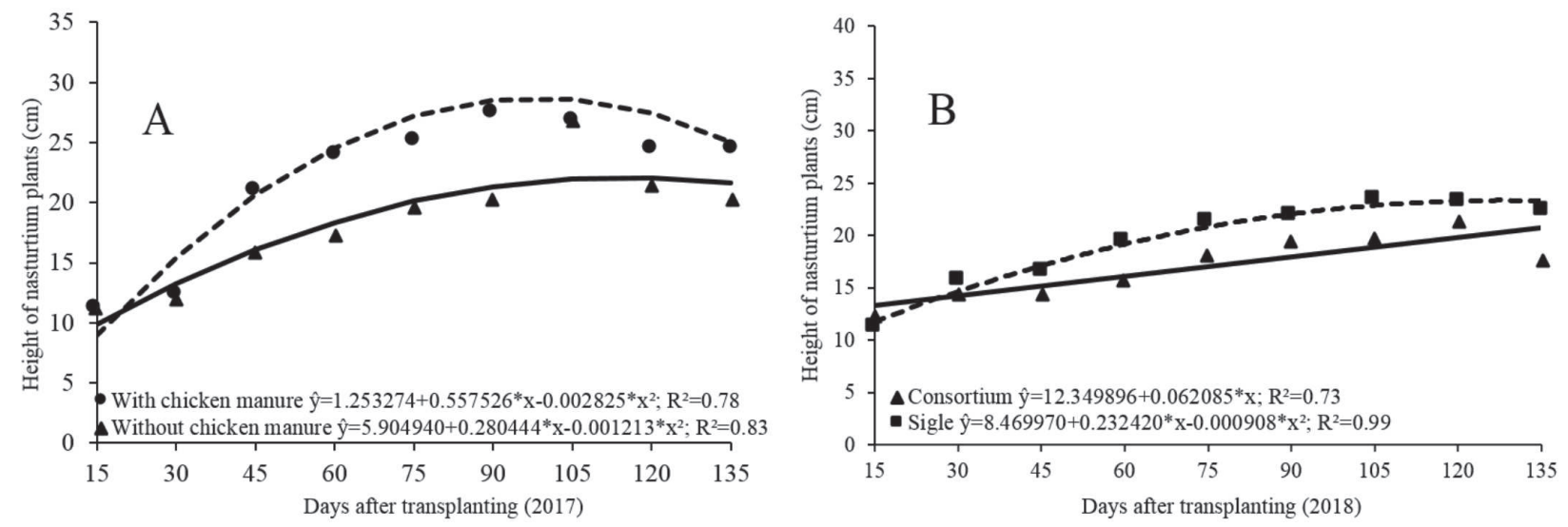

Figure 3: Height $(\mathrm{cm})$ of nasturtium as a function of addition of chicken manure to the soil, in 2017 (A) and as a function of intercropping, in 2018 (B).

Rev. Ceres, Viçosa, v. 66, n.5, p. 351-362, sep/oct, 2019 
plant $\left.^{-1}\right)$. No difference was found between treatments in the second cycle.

The principal component analysis (PCA) related the characteristics analyzed of vacum and nasturtium plants. Axis 1 explained $53.30 \%$ of data variation and axis 2 explained $42.02 \%$, totaling $95.32 \%$ of total data variability in vacum plants (Figure 4A). Regarding nasturtium plants, axis 1 explained $58.93 \%$ and axis 2 explained $33.10 \%$, totaling $92.03 \%$ of total data variability (Figure 4B).

Characteristics of vacum plants were separated into four groups. The first group comprised the monocropping with chicken manure, which was explained by height, FML, DML, LA, WUE, WUEi, A, chlorophyll $a, b$, and total, Ca-s, $\mathrm{N}-\mathrm{v}$, and Ca-v.

Table 3: Physiological parameters and chlorophyll $a, b$, and total indexes in vacum and nasturtium as a function of monocropping and intercropping with nasturtium, with and without chicken manure

\begin{tabular}{|c|c|c|c|c|c|}
\hline \multirow{3}{*}{ Parameters } & \multicolumn{2}{|c|}{ With chicken manure } & \multicolumn{2}{|c|}{ Without chicken manure } & \multirow{3}{*}{$\begin{array}{r}\text { C. V. } \\
(\%)\end{array}$} \\
\hline & \multicolumn{4}{|c|}{ Vacum } & \\
\hline & Monocrop & Intercrop & Monocrop & Intercrop & \\
\hline$\overline{C i\left(\mu \mathrm{mol} \mathrm{mol}^{-1}\right)}$ & $270.30 \pm 33.40 \mathrm{a}$ & $261.09 \pm 27.70 \mathrm{ab}$ & $242.33 \pm 23.55 \mathrm{~b}$ & $252.40 \pm 26.02 \mathrm{ab}$ & 10.53 \\
\hline$E\left(\mathrm{mmol} \mathrm{m}{ }^{-2} \mathrm{~s}^{-1}\right)$ & $3.22 \pm 0.92 \mathrm{~b}$ & $3.67 \pm 1.16 \mathrm{ab}$ & $3.43 \pm 1.47 \mathrm{ab}$ & $4.27 \pm 0.92 \mathrm{a}$ & 30.94 \\
\hline Gs $\left(\mathrm{mol} \mathrm{m} \mathrm{m}^{-2} \mathrm{~s}^{-1}\right)$ & $0.120 \pm 0.07 \mathrm{a}$ & $0.123 \pm 0.07 \mathrm{a}$ & $0.129 \pm 0.05 \mathrm{a}$ & $0.165 \pm 0.04 \mathrm{a}$ & 44.32 \\
\hline$A\left(\mu \mathrm{mol} \mathrm{m}{ }^{-2} \mathrm{~s}^{-1}\right)$ & $10.57 \pm 1.95 \mathrm{a}$ & $9.73 \pm 2.42 \mathrm{a}$ & $7.82 \pm 1.38 \mathrm{~b}$ & $7.85 \pm 1.97 \mathrm{~b}$ & 24.46 \\
\hline WUE $\left(\mathrm{mmol} \mathrm{CO}{ }^{2} \mathrm{~mol}^{-1} \mathrm{H}_{2} \mathrm{O}\right)$ & $3.45 \pm 0.73 \mathrm{a}$ & $2.72 \pm 0.36 \mathrm{ab}$ & $2.75 \pm 0.36 \mathrm{ab}$ & $2.31 \pm 0.50 \mathrm{~b}$ & 36.27 \\
\hline $\operatorname{ICE}\left(\mathrm{mol} \mathrm{m}^{-2} \mathrm{~s}^{-1}\right)$ & $0.032 \pm 0.003 \mathrm{a}$ & $0.031 \pm 0.007 \mathrm{a}$ & $0.034 \pm 0.004 \mathrm{a}$ & $0.033 \pm 0.007 \mathrm{a}$ & 25.69 \\
\hline$W U E i\left(\mu \mathrm{mol} \mathrm{mol}{ }^{-1}\right)$ & $86.94 \pm 27,14 \mathrm{a}$ & $83.00 \pm 11,15 \mathrm{ab}$ & $75.53 \pm 14,50 \mathrm{bc}$ & $73.32 \pm 13,64 \mathrm{c}$ & 14.43 \\
\hline Chlorophyll $a$ & $34.26 \pm 1.49 \mathrm{a}$ & $34.24 \pm 2.45 \mathrm{a}$ & $29.66 \pm 2.25 \mathrm{~b}$ & $28.43 \pm 2.72 b$ & 15.90 \\
\hline Chlorophyll $b$ & $14.66 \pm 0.45 \mathrm{a}$ & $13.61 \pm 0.75 \mathrm{a}$ & $13.44 \pm 28.47 \mathrm{a}$ & $10.48 \pm 0.46 \mathrm{a}$ & 40.38 \\
\hline \multirow[t]{2}{*}{ Chlorophyll total } & $48.93 \pm 1.94 \mathrm{a}$ & $47.86 \pm 3.20 \mathrm{a}$ & $41.40 \pm 3.44 \mathrm{~b}$ & $38.93 \pm 3.10 \mathrm{~b}$ & 15.26 \\
\hline & \multicolumn{4}{|c|}{ Nasturtium } & \\
\hline Chlorophyll $a$ & $31.67 \pm 1.68 \mathrm{a}$ & $31.18 \pm 2.09 \mathrm{a}$ & $27.64 \pm 2.84 \mathrm{~b}$ & $26.61 \pm 2.14 \mathrm{~b}$ & 9.32 \\
\hline Chlorophyll $b \quad 2018$ & $12.22 \pm 0.69 \mathrm{a}$ & $10.39 \pm 0.82 \mathrm{ab}$ & $8.72 \pm 0.45 \mathrm{bc}$ & $7.91 \pm 0.35 \mathrm{c}$ & 21.75 \\
\hline Chlorophyll total & $43.92 \pm 2.12 \mathrm{a}$ & $41.57 \pm 2.87 \mathrm{a}$ & $36.43 \pm 3.12 \mathrm{~b}$ & $34.59 \pm 2.16 \mathrm{~b}$ & 10.09 \\
\hline Chlorophyll $a$ & $30.66 \pm 4.46 \mathrm{a}$ & $30.72 \pm 3.47 \mathrm{a}$ & $24.02 \pm 1.45 \mathrm{~b}$ & $25.45 \pm 1.66 \mathrm{~b}$ & 14.40 \\
\hline Chlorophyll $b \quad 2019$ & $11.83 \pm 1.93 \mathrm{a}$ & $12.56 \pm 0.77 \mathrm{a}$ & $8.48 \pm 1.12 \mathrm{~b}$ & $8.66 \pm 0.53 \mathrm{~b}$ & 18.64 \\
\hline Chlorophyll total & $42.50 \pm 6.38 \mathrm{a}$ & $43.28 \pm 4.25 \mathrm{a}$ & $32.50 \pm 1.57 \mathrm{~b}$ & $34.10 \pm 2.12 \mathrm{~b}$ & 14.57 \\
\hline
\end{tabular}

Means followed by the same letters in the rows are not significantly different by the Tukey's test at the level of 5\% of probability ( $\mathrm{p}>$ 0.05). intercellular $\mathrm{CO} 2$ concentration $(C i)$, transpiration rate $(E)$, stomatal conductance $(g s)$, photosynthetic rate $(A)$, instantaneous water use efficiency (WUE), instantaneous carboxylation efficiency (ICE) and intrinsic water use efficiency (WUEi). C.V. - coefficient of variation.

Table 4: Effect of crop system and addition of chicken manure to the soil on the production fresh (FML) and dry (DML) mass of leaves and stems (FMS and DMS) and leaf area (LA) of vacuum at 540 DAT and nasturtium at 140 DAT in 2018

\begin{tabular}{|c|c|c|c|c|c|}
\hline \multirow{3}{*}{ Variables } & \multicolumn{2}{|c|}{ With chicken manure } & \multicolumn{2}{|c|}{ Without chicken manure } & \multirow{3}{*}{$\begin{array}{l}\text { C. V. } \\
(\%)\end{array}$} \\
\hline & \multicolumn{4}{|c|}{ Vacum } & \\
\hline & Monocrop & Intercrop & Monocrop & Intercrop & \\
\hline FML $\left(\right.$ g plant $\left.^{-1}\right)$ & $247.02 \pm 25.98 \mathrm{a}$ & $142.86 \pm 5.34 \mathrm{ab}$ & $235.32 \pm 18.35 \mathrm{a}$ & $117.38 \pm 7.57 \mathrm{~b}$ & 36.29 \\
\hline DML $\left(\right.$ g plant $\left.^{-1}\right)$ & $79.32 \pm 9.23 \mathrm{a}$ & $39.54 \pm 2.97 \mathrm{ab}$ & $68.65 \pm 5.30 \mathrm{ab}$ & $31.83 \pm 2.75 \mathrm{~b}$ & 47.65 \\
\hline FMS $\left(\right.$ g plant $\left.^{-1}\right)$ & $186.25 \pm 30.22 \mathrm{a}$ & $120.46 \pm 9.57 \mathrm{a}$ & $178.51 \pm 21.16 \mathrm{a}$ & $120.95 \pm 12.50 \mathrm{a}$ & 63.69 \\
\hline DMS (g plant $\left.{ }^{-1}\right)$ & $104.76 \pm 14.39 \mathrm{a}$ & $72.70 \pm 4.59 \mathrm{a}$ & $99.33 \pm 9.48 \mathrm{a}$ & $72.93 \pm 5.77 \mathrm{a}$ & 51.10 \\
\hline \multirow[t]{2}{*}{ LA $\left(\mathrm{cm}^{2}\right.$ plant $\left.^{-1}\right)$} & $8318.04 \pm 80.22 \mathrm{a}$ & $4354.83 \pm 20.05 \mathrm{bc}$ & $7400.81 \pm 50.62 \mathrm{ab}$ & $3787.78 \pm 20.79 \mathrm{c}$ & 36.21 \\
\hline & \multicolumn{4}{|c|}{ Nasturtium } & \\
\hline FML (g plant $\left.{ }^{-1}\right)$ & $164.00 \pm 11.11 \mathrm{a}$ & $57.50 \pm 3.31 \mathrm{~b}$ & $84.25 \pm 2.38 \mathrm{ab}$ & $42.75 \pm 2.18 b$ & 63.26 \\
\hline DML $\left(\mathrm{g}_{\text {plant }}{ }^{-1}\right)$ & $19.75 \pm 13.54 \mathrm{a}$ & $8.75 \pm 4.48 \mathrm{ab}$ & $10.25 \pm 5.38 \mathrm{ab}$ & $6.25 \pm 3.39 \mathrm{~b}$ & 65.62 \\
\hline FMS $\left(\right.$ g plant $\left.^{-1}\right)$ & $73.75 \pm 7.38 \mathrm{a}$ & $27.00 \pm 1.32 \mathrm{a}$ & $47.00 \pm 3.15 \mathrm{a}$ & $24.00 \pm 1.33 \mathrm{a}$ & 90.08 \\
\hline DMS (g plant $\left.{ }^{-1}\right)$ & $11.75 \pm 7.46 \mathrm{a}$ & $4.50 \pm 2.32 \mathrm{a}$ & $7.25 \pm 4.04 \mathrm{a}$ & $4.00 \pm 1.79 \mathrm{a}$ & 64.55 \\
\hline LA $\left(\mathrm{cm}^{2}\right.$ plant $\left.^{-1}\right)$ & $2097.25 \pm 20.32 \mathrm{a}$ & $1525.75 \pm 50.44 \mathrm{ab}$ & $1001.75 b c \pm 40.43$ & $754.00 \pm 10.73 \mathrm{c}$ & 31.58 \\
\hline
\end{tabular}

Means followed by the same letters in the rows are not significantly different by the Tukey's test at the level of 5\% of probability (p > 0.05). C.V. - coefficient of variation. 
The second group (Figure 4A) comprised the intercropping of vacum with nasturtium with addition of chicken manure, which was explained by the variables $\mathrm{SB}$, $\mathrm{K}-\mathrm{s}, \mathrm{V} \%, \mathrm{P}-\mathrm{s}, \mathrm{Cu}-\mathrm{v}, \mathrm{Zn}-\mathrm{v}, \mathrm{pH}$, and $\mathrm{P}-\mathrm{v}$. The third group comprised the monocropping of vacum without addition of chicken manure, which was explained by $\mathrm{H}+\mathrm{Al}$ and $\mathrm{CEC}$, and the fourth group corresponded to the intercropping without addition of chicken manure, which was explained by F-s and $C i$.
Characteristics of nasturtium were separated into four groups. The first group comprised the monocropping with chicken manure, which was explained by FML, FM FL, DM FL, LA, $E$, WUE, Mn-v, Cu-v, chlorophyll $a, b$, and total (Figure 4B).

The second group comprised the intercropping of nasturtium with addition of chicken manure, which was explained by SB, K-s, V\%, Mg-v, Ca-v, and $\mathrm{Ci}$. The third and fourth groups corresponded to monocropping of

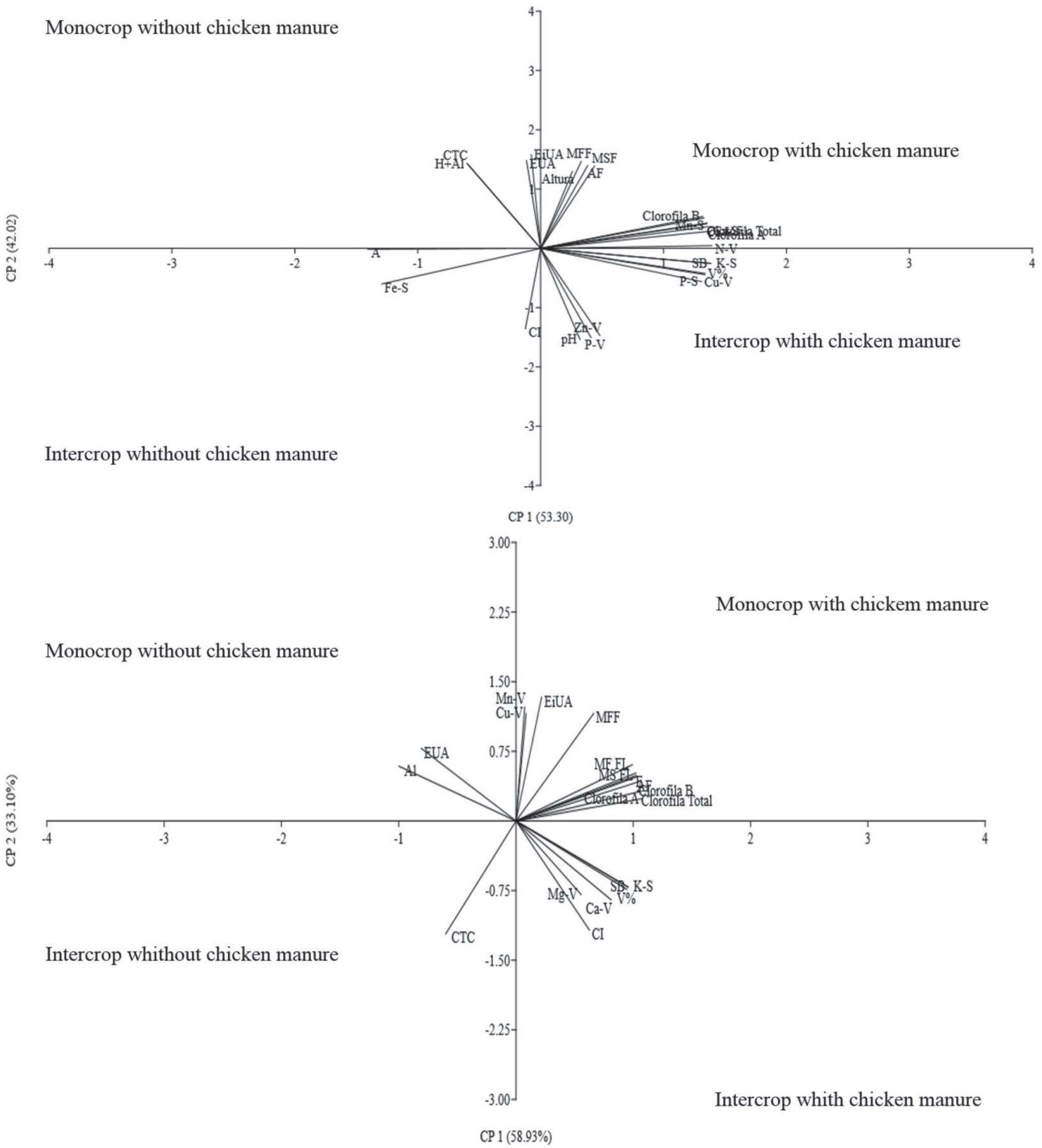

Figure 4: Principal component analysis (PCA) of variables related to growth, production, physiological parameters, and chemical characteristics of plant and soil material as a function of monocrop and intercrop systems, with and without addition of chicken manure to the soil. $\mathrm{Ca}-\mathrm{p}=$ plant calcium; $\mathrm{P}-\mathrm{p}=$ plant phosphorus, $\mathrm{K}-\mathrm{s}=$ soil potassium; Fe-s = soil iron; Ca-s = soil calcium, Zn-p $=$ plant zinc, $\mathrm{Cu}-\mathrm{p}=$ plant copper; $\mathrm{K}-\mathrm{p}=$ plant potassium, $\mathrm{Mn}-\mathrm{p}=$ plant manganese . 
nasturtium and intercropping without addition of chicken manure and were explained by $\mathrm{Al}$ and $W U E$ and CEC, respectively (Figure 4B).

Intercropping efficiencywas calculated according to values of Equivalent Area Ratio (EAR) as 1.16 and 1.18 for the treatments without and with chicken manure, respectively, and therefore it was considered efficient.

\section{DISCUSSION}

The intercropping and the addition of chicken manure favored $\mathrm{P}$ adsorption by soil, due to its anionic character, since the sites electrostatically attract cations such as $\mathrm{Ca}$, $\mathrm{Fe}$, and $\mathrm{Al}$, which induce $\mathrm{P}$ retention (Sá et al., 2017). According to the classification by Raij (2017), the P content in the soil found in this study is considered high ( $>41$ $\mathrm{mmol}_{\mathrm{c}} \mathrm{dm}^{-3}$ ). These results corroborate the study of Rodrigues et al. (2016) who evaluated the intercropping of Acacia mangium Willd., native to Brazil, with Pueraria phaseoloides (Roxb.) Benth, forage Fabaceae, and reported improvement of soil chemical attributes.

Species native to the Cerrado such as vacum occur in areas of acid and low fertility soils, therefore, they are adapted to the soil conditions where this study was performed (Knapik et al., 2005; Umeo et al., 2011). Nevertheless, the OM content was satisfactory for the effectiveness of CEC, supplying of nutrients such as $\mathrm{P}$ and $\mathrm{K}$, maintenance of $\mathrm{pH}$, and reduction of $\mathrm{Al}$ content. This is a consenquence of the mineralization process that transforms organic material into organic substances by increasing the negative charges of the soil and raising the pH (Sá et al., 2017). In in this study, the nutrient contents in vacum were within the range considered suitable, according to Raij (2017), for crop development: $\mathrm{N}\left(40-60 \mathrm{~g} \mathrm{~kg}^{-1}\right), \mathrm{P}\left(3-7 \mathrm{~g} \mathrm{~kg}^{-1}\right), \mathrm{K}\left(1-5 \mathrm{~g} \mathrm{~kg}^{-1}\right), \mathrm{Ca}\left(4-40 \mathrm{~g} \mathrm{~kg}^{-}\right.$ $\left.{ }^{1}\right), \mathrm{Cu}\left(5-30 \mathrm{mg} \mathrm{dm}^{-3}\right), \mathrm{Mn}\left(20-300 \mathrm{mg} \mathrm{dm}^{-3}\right)$, and $\mathrm{Zn}(27-150$ $\left.\mathrm{mg} \mathrm{dm}{ }^{-3}\right)$.

The treatment intercropping without chicken manure resulted in greater foliar $\mathrm{P}$ content in vacum plants, probably because it is an undemanding native species adapted to use $\mathrm{P}$ more efficiently. The concentration of $\mathrm{P}$ in the soil solution is low which is considered a limiting factor to more demanding plants, like nasturtium, due to the strong adsorption to iron oxides and aluminum from the clay fraction (Rodrigues et al., 2016; Raij, 2017). P stimulates root growth and enhances reproductive growth, as it is a constituent of the cytoplasmic and nuclear proteins and has important role in the carbohydrates metabolism and energy transfers (Taiz et al., 2017).

The importance of high foliar K content in nasturtium is because of its role in cellular osmotic regulation, activation of enzymes in the photosynthesis, and respiration processes, consequently, leading to a greater growth rate and flower maturation (Taiz et al., 2017).
The higher nutrient content in leaf dry mass of nasturtium, in relation to vacum, indicates that this species requires higher amounts of these nutrients for leaf formation, as well as to meet the metabolic demands of flowers produced along the cultivation cycle (Jakubczyk et al., 2018).

Vacum had greater height and diameter of stem in monocropping due to the lack of competition with nasturtium. The height values in these treatments were greater than those reported by Knapik et al. (2005) for the same species propagated by seeds and cultivated with mineral fertilization; they observed maximum height of $8.02 \mathrm{~cm}$ at 120 DAT. They also found that the plant was not responsive to fertilization, indicating lower demand for nutrients and slow growth over the years. The increase in stem diameter with addition of chicken manure is result from the effects on greater nutrient availability as well as improvements in physical, chemical, and microbiological characteristics of soil (Kiehl, 1985).

The fact that chicken manure contributed to growth of nasturtium corroborates the findings of Sangalli et al. (2004), who reported that the improved nutrient availability, infiltration, and water retention resulting from the use of organic waste contributed to the growth of nasturtium, mainly at the beginning of the crop cycle. In addition, Moraes et al. (2007) observed mean height of $21.05 \mathrm{~cm}$ in in full bloom nasturtiums at 70 DAT.

Nasturtiums are more demanding in nutritional terms than vacum plants (Jakubczyk et al., 2018); hence, the greater growth rate in monocropping is a result of less competition for nutrients, light, water, oxigen, and others. The lower growth in 2018 is due to high rainfall and high temperatures, which reduced plant growth, since the species is adapted to mild temperatures, with mean of $21.61{ }^{\circ} \mathrm{C}$.

Gas exchange in vacum was greater by the effect of chicken manure on soil chemical properties, increasing the contents of $\mathrm{P}$ and $\mathrm{Mg}$, which act as cofactors in enzymes of energetic metabolism, in the chlorophyll molecule, and conversion of light energy into ATP (Oliveira et al., 2018). Moreover, the nutrients provided by chicken manure can contribute to the transport and absorption of ions and speed of enzymatic reactions of the Krebs cycle, resulting in increased production of metabolic energy and increasing the synthesis of nucleic acids (Taiz et al., 2017).

As a consequence, there was a significant increase in shoot growth of vacum, favoring the exposure of leaves to direct sunlight and photoassimilates production (Taiz et $a l ., 2017)$. The increase in the values of chlorophyll $a$ and total indices in vacum are due to the beneficial effects of chicken manure on nutrient availability, namely $\mathrm{N}, \mathrm{Mg}, \mathrm{P}$, and micronutrients, which are related to photosynthesis and constituents of chlorophyll molecule (Armond et al., 
2016). Studies assessing chlorophyll index with addition of organic fertilizers resulted in favorable effects, as reported by Sales et al. (2018) on Schinus terebinthifolius fertilized with tannery sludge, waste from coffee roasting industry, and cow manure.

Water use efficiency (WUEi) and instantaneous water use efficiency (WUE) were greater in vacum because of the species ability to regulate gas exchange, by decreasing stomatal conductance and transpiration more than $\mathrm{CO}_{2}$ assimilation, saving water for each $\mathrm{CO}_{2}$ molecule assimilated (Taiz et al., 2017).

Greater evapotranspiration and photorespiration and lower efficiency of Rubisco in vacum plants without chicken manure led to lower growth rate, since the reduction in mesophyll metabolism limits $\mathrm{CO}_{2}$ absorption in the chloroplasts (Taiz et al., 2017).

The concentrations of chlorophyll $a, b$ and total were higher in nasturtium with addition of chicken manure. This result is due to greater foliar $\mathrm{N}$ content, which is important for photosynthesis and plant growth as a constituent of the chlorophyll molecule (Armond et al., 2016). The chlorophyll $b$ index enables the capture of larger amount of incident light and channel it to the sites of action of photosystems, thus providing greater ATP and NADPH formation (Sales et al., 2018).

The lowest intercellular $\mathrm{CO}_{2}$ concentration in nasturtium, in the 2017 cycle, stimulated stomatal opening, allowing entry of $\mathrm{CO}_{2}$ to support high photosynthetic rates and instantaneous water use efficiency. The decrease in stomatal conductance along the crop cycle, regardless of the intercropping and addition of chicken manure, led to senescence and leaf fall, emergence of structures, and assimilating tissues (Taiz et al., 2017), therefore causing reduction in height and plant productivity.

When the leaves began the senescence process, the photosynthetic rates began to decrease due to chlorophyll degradation (Taiz et al., 2017), with a progressive reduction of gas exchange, with minimum values at 120 DAT; thereby the reduction in plant height, which was more intense in the second cultivation cycle.

The photosynthetic rate $(A)$ during the second cycle of nasturtium was higher in the intercropping with chicken manure because of the nutrient release to the soil, improving chemical conditions and, consequently, the gas exchanges that contribute to plant growth (Andrade et al., 2015; Sá et al., 2017). Oliveira et al. (2018) reported similar results, with increase in $A, E$ and WUE in plants of Lycopersicon lycopersicum var. Cerasiforme cultivated with chicken manure.

Production of leaves in monocropped vacum was greater due to better adaptation and less competition between plants for water, nutrients, light, and $\mathrm{CO}_{2}$, together with the addition of chicken manure, contributing to a higher organic matter content. C-related nutrients, like $\mathrm{N}$ and $\mathrm{P}$, are released from microbial cells to the soil as mineral, making them available for absorption by plants, thus, contributing to growth and productivity (Malavolta, 2006; Andrade et al., 2015; Jakubczyk et al., 2018).

Different results were reported by Knapik et al. (2005), studying the effect of mineral fertilization $[(\mathrm{NH},),, \mathrm{SO}$, , $\mathrm{P}_{2} \mathrm{O}_{5}$ and $\left.\mathrm{KCl}\right]$ on vacum. The authors found no response regarding fresh mass of leaf and stem and concluded that species native to Cerrado are undemanding for fertilization. The positive response to organic fertilization in this study results from the different conditions of soil, climate, and others, it is, therefore, important to produce more leaf mass and consequently more secondary metabolites (Knapik et al., 2005; Torales et al., 2014; Trevizan et al., 2016).

Agronomic practices that improve vacum yield are key to phytotherapy, because the essential oil is produced in the leaves. Vacum oil has viridiflorol $(30.88 \%)$ as main constituent. It is used against Mycobacterium tuberculosis, and as a natural antiinflammatory, antimycobacterial and antioxidant (Trevizan et al., 2016).

Studies performed by Tirloni et al. (2015), Trevizan et al. (2016) and Umeo et al. (2011) proved the benefits of flavonoids and phenolic compounds from essential oil of vacum, highlighting the importance of cropping systems to increase productivity, since the exploitation of genetic resources and extractive harvest of Cerrado can lead to reduction of natural resources and even extinction of native species (Oliveira et al., 2015; Fernandes et al., 2016; Jeromini et al., 2018).

The great genetic variability of the species accounts for the low fruit production, therefore few plants flowered and set fruit in the short cycle period. Along the crop cycle, the variation would decrease and yield would increase. It is of note that fruit production in large quantities is not desirable when it is to be used as medicinal plant, since the leaves are the organs used for this purpose (Tirloni et al., 2015; Trevizan et al., 2016).

The high leaf dry mass production and large leaf area of nasturtium were consistent with the growth rate, which was higher in the monocropping with chicken manure. The monocropping contributed to a better use of nutrients provided by the chicken manure. Similar results were found by Sangalli et al. (2004), who observed fresh $(52195.69 \mathrm{~kg}$ $\left.\mathrm{ha}^{-1}\right)$ and dry $\left(6281.14 \mathrm{~kg} \mathrm{ha}^{-1}\right)$ biomass increment of shoots of nasturtium with chicken manure. Moraes et al. (2007) found that the production of monocropped nasturtium was greater in number $(13,298,500)$, fresh mass $\left(8.86 \mathrm{t} \mathrm{ha}^{-1}\right)$, and dry mass $\left(0.70 \mathrm{t} \mathrm{ha}^{-1}\right)$ than intercropped with cabbage $\mathrm{cv}$. "chato de quintal", indicating a better adaptability in the monocropping.

The production of nasturtium flowers, overall, can be considered low compared with results of other studies 
(Sangalli et al., 2004; Moraes et al., 2007). In the treatment without chicken manure, $\mathrm{Zn}$ content was below the optimum ( $8.5 \mathrm{mg} \mathrm{dm}^{-3}$ ) (Raij, 2017), growth rate was lower and, consequently, flower production was low. This hypothesis corroborates the results found by Carbonari et al. (2006), who found that nasturtium is a more demanding plat for $\mathrm{ZnCl}_{2}$ fertilization.

The PCA groups that comprised the vacum characteristics were created because of the addition of chicken manure, which increased the nutrient content of the soil (Kiehl, 1985), improving $N$ content responsible for photosynthesis, and chlorophyll $a$ and total, thereby improving growth and productivity of plants. The greater foliar P content is involved in energy transfer (ATP), necessary for the photosynthesis, in addition to being the final product of enzymatic reactions of carbohydrate metabolism (Raij, 2017; Taiz et al., 2017).

Without chicken manure, there was a reduction in CEC, diminishing availability of essential nutrients for plants and reducing the vegetative growth capacity and yield of vacum plants. Probably, the greater solubility of aluminum was toxic and iron increased with acidity, thus, the microorganism population responsible for decomposition of organic matter decreased (Sá et al., 2017).

Therefore, the monocropping of vacum with chicken manure was more efficient regarding the characteristics assessed, hence, greater growth rate and yield. The PCA groups comprising the nasturtium characteristics occurred because monocropped nasturtium with addition of chicken manure was more responsive to the characteristics assessed.

The intercropping efficiency, regardless of the addition of chicken manure to the soil, evaluated by EAR was greater than 1.0. This resulted from the use of species with different metabolisms and growth cycles. In order to obtain the same production in monoculture it would be necessary increases of $16 \%$ and $18 \%$ in area. Therefore, the intercropping provides better use of area, nutrients, irrigation, and reduction of cultivation practices.

\section{CONCLUSIONS}

Vacum had greater height growth and production of leaf fresh and dry masses in monocropping with addition of chicken manure to the soil.

Nasturtium had greater growth rate and flower production in monocropping with addition of chicken manure, in the first cultivation cycle.

The intercropping of vacum and nasturtium was effective, with Equivalent Area Ratios (EAR) of 1.16 and 1.18 without and with chicken manure, respectively.

In this study, the intercropping of vacum and nasturtium with addition of chicken manure was found feasible.

\section{REFERENCES}

Alvares CA, Stape JL, Sentelhas PC, Gonçalves JLM \& Sparovek G (2013) Koppen's climate classification map for Brazil. Meteorologische Zeitschrift, 22:711-728.

Andrade CA, Bibar MPS, Coscione AR, Pires AMM \& Soares ÁG (2015) Mineralização e efeitos de biocarvão de cama de frango sobre a capacidade de troca catiônica do solo. Pesquisa Agropecuária Brasileira, 50:407-416.

Armond VC, Gonzalez SDP, Oliveira FER, Silva RM, Leal TTB, Reis AS \& Silva F (2016) Initial development of Italian Zucchini plants cultivated with worm humus. Horticultura Brasileira, 34:439-442.

Bonamigo T, Scalon SPQ \& Pereira ZV (2016) Substrates and levels of light intensity on initial growth of seedlings of Tocoyena formosa (Cham. \& Schltdl.) K. Schum. (RUBIACEAE). Ciência Florestal, 26:501-511.

Bortolini J, Tessaro D, Gonçalves MS \& Oro SR (2017) Lodo de esgoto e cama de aviário como componente de substratos para a produção de mudas de Cedrela fissilis e Anadenanthera macrocarpa (Benth). Brenan. Scientia Agraria,18:121-128.

Brito AU, Puiatti M, Cecon PR, Finger FL \& Mendes TDC (2017) Viabilidade agroeconômica dos consórcios taro com brócolis, couve-chinesa, berinjela, jiló, pimentão e maxixe. Revista Brasileira de Ciências Agrárias, 12:296-302.

Caetano LCS, Ferreira JM \& Araújo M (1999) Produtividade da alface e cenoura em sistema de consorciação. Horticultura Brasileira, 17:143-146

Carbonari VB, Vieira MC, Heredia NAZ \& Marchetti ME (2006) Phosphorus and chicken manure on development and yield of Tropaeolum majus L. Brazilian Journal of Medicinal Plants, 8:71-77.

Costa AM, Borges EN, Silva AA, Nolla A \& Guimarães EC (2009) Potencial de recuperação física de um Latossolo Vermelho, sob pastagem degradada, influenciado pela aplicação de cama de frango. Ciência e Agrotecnologia, 33:1991-1998.

Embrapa- Empresa Brasileira de Pesquisa Agropecuária (2013) Sistema brasileiro de classificação de solos. $3^{\mathrm{a}}$ ed. Rio de Janeiro, Embrapa solos. 306p.

Fernandes GW, Aguiar LMS, Anjos AF, Bustamante M, Collevatti RG, Dianese JC, Diniz S, Ferreira GB, Ferreira LG, Ferreira ME, Françoso RD, Langeani F, Machado RB, Marimon BS, Marimon Junior BH, Neves AC, Pedroni F, Salmona Y, Sanchez M, Scariot AO, Silva JÁ, Silveira LF, Vasconcelos HL \& Colli GR (2016) Cerrado: um Bioma rico e ameaçado. In: Peixoto AL, Luz JRP \& Brito MA (Eds.) Conhecendo a biodiversidade. Brasília, MCTIC, CNPq, PPBio. 196p.

Jakubczyk K, Janda K, Watychowicz K, £ukasiak J \& Wolska J (2018) Garden nasturtium (Tropaeolum majus L.)-a source of mineral elements and bioactive compounds. Roczniki Panstwowego Zakladu Higieny, 69:119-126.

Jeromini TS, Mota LH de S, Scalon S de PQ, Dresch DM \& Scalon LQ (2018) Effects of substrate and water availability on the initial growth of Alibertia edulis Rich. Floresta, 49:089-098.

Knapik JG, Almeida LS, Ferrari MP, Oliveira EB \& Nogueira AC (2005) Crescimento inicial de Mimosa scabrella Benth., Schinus terebinthifolius Raddi e Allophylus edulis (St. Hil.) Radl. sob diferentes regimes de adubação. Pesquisa Florestal Brasileira, 51:01- 33 .

Kiehl EJ (1985) Fertilizantes orgânicos. São Paulo, Agronômica Ceres. $492 \mathrm{p}$ 
Malavolta E (2006) Manual de nutrição mineral de plantas. São Paulo, Ceres. 638p.

Melo AC, Costa SCA, Castro AF, Souza ANV, Sato SW, Líverob FAR, Lourenço ELB, Baretta IP \& Lovato ECW (2018) Hydroethanolic extract of Tropaeolum majus promotes anxiolytic effects on rats. Revista Brasileira de Farmacognosia, 28:589-593.

Moraes AA, Vieira M do C \& Zárate NAH (2007) Produção de repolho 'Chato de Quintal' e da capuchinha 'Jewel', solteiros e consorciados, sem e com cama-de-frango semidecomposta incorporada no solo. Ciência e Agrotecnologia, 31:731-738.

Oliveira MC, Ribeiro JF, Passos FB, Aquino F de G, Oliveira FF \& Sousa SR (2015) Crescimento de espécies nativas em um plantio de recuperação de Cerrado sentido restrito no Distrito Federal, Brasil. Revista Brasileira de Biociências, 13:25-32.

Oliveira LKB, Costa RS, Santos JLG, Lima F de O, Amorim AV \& Marinho AB (2018) Respostas fisiológicas de tomateiros cereja a diferentes fontes de adubos orgânicos. Revista Brasileira de Agricultura Irrigada, 12:2799-2807.

Raij BV (2017) Fertilidade do solo e manejo de nutrientes. $2^{\mathrm{a}}$ ed. Piracicaba, International Plant Nutrition Institute. 420p.

Rogeri DA, Ernani PR, Lourenço KS, Cassol PC \& Gatiboni LC (2015) Mineralização e nitrificação do nitrogênio proveniente da cama de aves aplicada ao solo. Revista Brasileira de Engenharia Agricola e Ambiental, 19:534-540.

Rodrigues PG, Ruivo MLP, Piccinin JL \& Jardim MAG (2016) Contribuição dos atributos químicos do solo no desenvolvimento vegetativo do paricá em diferentes sistemas de cultivo. Ciência Florestal, 26:59-68.

Sá JM, Jantalia CP, Teixeira PC, Polidoro JC, Benites V de M \& Araújo AP (2017) Agronomic and P recovery efficiency of organomineral phosphate fertilizer from poultry litter in sandy and clayey soils. Pesquisa Agropecuária Brasileira, 52:786-793.
Sales RA, Sales RA, Santos RA, Quartezani WZ, Berilli S da S \& Oliveira EC (2018) Influência de diferentes fontes de matéria orgânica em componentes fisiológicos de folhas da espécie Schinus terebinthifolius Raddi. (Anacardiaceae). Scientia Agraria, 19:132-141.

Sangalli A, Vieira M do C \& Zárate NAH (2004) Organic residue and nitrogen on the biomass production of nasturtium (Tropaeolum majus L.) 'Jewel'. Ciência e Agrotecnologia, 28:831-839.

Sneath PH \& Sokal RR (1973) Numerical taxonomy: the principles and practice of numerical classification. San Francisco, W. H. Freeman and Company. 573p.

Taiz L, Zeiger E, Moller IM \& Murphy A (2017) Fisiologia e Desenvolvimento Vegetal. $6^{\mathrm{a}}$ ed. Porto Alegre, Artmed. 858p.

Tirloni CAS, Macorini LFB, Santos UP, Rocha P dos S, Barros SV, Melo AMMF, Vieira M do C, Souza K de P \& Santos EL (2015) Evaluation of the antioxidant activity, antimicrobial effect and acute toxicity from leaves of Allophylus edulis (A. St.-Hil., A. Juss. Cambess.) Hieron. ex Niederl. African Journal of Pharmacy and Pharmacology, 9:353-362.

Torales EP, Zárate NAH, Vieira M do C, Gassi RP, Salles NA \& Pinto JV da C (2014) Influência da cama de frango e de espaçamentos entre plantas na produtividade agroeconômica de mandioquinha-salsa. Revista Ceres, 61:162-171.

Trevizan LNF, Nascimento KF, Santos JA, Kassuya CAL, Cardoso CA, Vieira M do C, Moreira FMF, Croda J \& Formagio ASN (2016) Anti-inflammatory, antioxidant and anti-Mycobacterium tuberculosis activity of viridiflorol: The major constituent of Allophylus edulis (A. St.-Hil., A. Juss. \& Cambess.) Radlk. Journal of ethnopharmacology, 192:510-515.

Umeo SH, Ito TM, Yokota ME, Romagnolo MB \& Laverde Junior A (2011) Avaliação das propriedades antioxidantes, anticolinesterásicas e citotóxicas dos frutos de Allophylus edulis (A. St.-Hil., A. Juss. Cambess.) Hieron. ex Niederl (Sapindaceae). Arquivos de Ciências da Saúde da UNIPAR, 15:167-171. 